\title{
Indian project will safeguard genetic value of plants
}

\begin{abstract}
New Delhi. The Indian government has launched a major project to develop genetic 'profiles' of plants used for medicinal purposes as protection against the potential theft and patenting of useful genes by multinational drug companies.
\end{abstract}

The US\$5-million project is part of a programme on conservation of medicinal and aromatic plants funded by the Department of Biotechnology, under which a gene bank will be established in the Tropical Botanical Gardens and Research Institute (TBGRI) in Trivandrum in Kerala state.

The bank, which will maintain the DNA library, will also keep in a state of cryopreservation the tissue, pollen and seeds of plants identified after rapid screening as having medicinal value.

A trust named after Rajiv Gandhi, the late prime minister, has provided funds for the purchase of equipment, while three specialized microbiological institutes will assist TBGRI in carrying out the DNA profiling. The gene bank will be completed by 1998 , and will contain up to 10,000 samples, with their genetic profiles.

The creation of the gene bank is a direct result of the biodiversity convention signed in Rio de Janeiro in 1992, which gives sovereign rights over plant genetic resources to the states in which they are found. "The DNA fingerprints will help us stake our claim if a foreign pharmaceutical company seeks a patent for a drug based on a plant species taken out of India," says Palpu Pushpangadan, director of TBGRI.

Pushpangadan points out, for example, that the widely patented neem products distributed in the United States are based on extracts from the neem (margosa) tree imported from India. Similarly, the world's entire supply of isabgol (pyslium), a traditional remedy for constipation, comes from the Indian subcontinent. But the government receives no royalties for isabgol products processed and sold by multinational pharmaceutical companies.

Pushpangadan says that although many medicinal herbs have already been taken out of the country, "India is still left with a rich genetic diversity that must be conserved and protected from theft". He says his gene bank could supply material for research by foreign companies, but on condition that India holds the patent on any resulting product.

Given the country's new patent regime, and the lack of its own resources for developing synthetic drugs, India's main strength lies in its medicinal plants, he says. For example, his institute is planning to file a patent on a drug from Tricopus eylanicus, the Indian equivalent of Chinese ginseng.

K.S. Jayaraman

\section{Even excellence is no longer good enough for the NSF}

Washington. A senior biophysicist is taking the National Science Foundation (NSF) to task over its grant selection process which, he says, often fails to fund proposals that are graded as 'excellent' in some fields, while finding money to support lowergrade proposals in others.

Oleg Jardetzky, director of the magnetic resonance laboratory at Stanford University in California, says that in the past year NSF's molecular biophysics programme has rated three proposals from his laboratory as 'excellent' or 'very good', only to reject them.

Having collected evidence that the funding situation in other programmes is less fiercely competitive, Jardetzky has written to Neal Lane, director of NSF, saying that he may offer testimony to Congress that NSF's funding process is "an arbitrary, and hence wasteful distribution of public funds".

NSF says that all its programmes are heavily oversubscribed, and the success rate in Petersen: issue will the biophysics pro- grow In importance. gramme last year,

although low, was not abnormally so. But the agency, which spent more than $\$ 2$ billion last year on university research, says that it expects many more complaints like Jardetzky's. "As money gets tighter, this issue is going to become more important," says Anne Petersen, deputy director of the NSF.

According to Jardetzky, the biophysics programme was able to fund only 18 proposals last year out of 28 graded 'excellent' and 79 considered fundable - a success rate of 22 per cent. In a letter responding to his initial complaint, Mary Clutter, assistant director for biological sciences at NSF, said that $30-50$ per cent of applications were considered fundable across her directorate, and that overall about a quarter of all applications received by the science agency were funded.

Jardetzky interprets this as meaning that more than half of suitable applications are in fact funded - and wants to know why only one-fifth of such applications succeed in biophysics. But Clutter says it is unfair to draw a comparison between broad estimates for the whole of the directorate and specific figures which only cover one year in one programme.

In some disciplines, she says, 80 per cent of proposals are considered fundable. The overall success rate of 25 per cent varies widely between programmes, the variation depending on factors such as the extent to which NSF's funding responsibility overlaps with that of other agencies.

In many programmes, more proposals are graded 'excellent' than can be funded, NSF officials say. But these programmes are not necessarily those with the highest priority; they may simply be the ones whose study panels are most inclined to give 'excellent' grades.

Although the NSF tries to impose common assessment standards across all fields, equivalence between 'excellent' proposals in, say, electrical engineering and cell biology, may mean little.

That is why the NSF, as it has expanded over the years, has moved towards a system where it divides its money into separate programmes. The result, according to Jardetzky, is that the biophysics programme has become "a straitjacket", unable to meet the needs of scientists who depend on it.

Petersen says that some members of the NSF's governing body, the National Science Board, agree with Jardetzky that it would be better "just to take what comes in and fund the best work". But the size of the NSF today - as well as its accountability to Congress - makes a quick return to this utopian principle unlikely.

NSF also says that an independent 'committee of visitors' regularly inspects the handling of research proposals in each division. Two years ago, such a committee looked at the division of molecular and cellular biosciences, including the biophysics programme. The committee came to the conclusion that it was happy with the overall quality of review, but noted that "marginal budgets result in a great deal of excellent science being either underfunded or unfunded".

Furthermore, Jardetzky's threat to testify in Congress against NSF's funding practices may prove to be empty, as the science agency does not have any real enemies on Capitol Hill to take him up on it.

But he does promise to raise the matter with the National Academy panel, headed by former president Frank Press, on how the US government distributes its science funding (see Nature 372, 5; 1995). And whatever the Press panel makes of Jardetzky's complaint, it is still expected to address the growing problem faced by science funding agencies: how to maintain the peer review system intact when it is not possible to fund all the work that peers deem excellent.

Colin Macilwain 